\title{
Dump Design and Stability Analysis of Jinping Bay river Iron ore on Yunnan province
}

\author{
Huai Xiaobin \\ Faculty of Land Resource Engineering, Kunming \\ University of Science and Technology, \\ Kunming, Yunnan, 650093, China \\ email:416500542@qq.com
}

\author{
Huang Deyong \\ Faculty of Land Resource Engineering, Kunming \\ University of Science and Technology, \\ Kunming, Yunnan, 650093, China \\ email: 76336836 @qq.com
}

\author{
Ma Wei \\ Faculty of Land Resource Engineering, Kunming \\ University of Science and Technology, \\ Mineral Resources Prediction and Evaluation \\ Engineering Laboratory of Yunnan Province,Kunming, \\ Yunnan, 650093, China \\ e-mail:378486149@qq.com
}

\begin{abstract}
This paper discusses a programming problem with dump design in Bay river iron on Yunnan province. In order to solve the problem efficiently, Firstly we analysis the conditions about the geological, then design the dump of Jinping Bayriver iron on Yunnan province. However, the stability is very important for it, so we must evaluate the stability After calculation, indicating that the dump is stable . Dump stability computations premise is original geological terrain slope below the slip plane does not exist, design thought should also be considered in the proof of groundwater erosion, but because of the extent of the impact is difficult to make a judgment according to the available information, Calculated, assuming a potential slip plane "ABCF" stability factor FS2 $=1.31>[F S]=1.15 \sim 1.30$, indicating that the assumptions underlying the slip plane "ABCF" does not exist, is stable.
\end{abstract}

Keywords- dump design; stability; Iron ore;safety;analysis

\section{INTRODUCTION}

Jinping Mianhuadi iron mine from Maan motton, Bay River, a large slope, volcanoes, three slope and other mineral segments. Maanshan, Bay River, Ore segment overall slope NW-SW trending linear zonal distribution. Total length of 5000 meters and a width of 200 to $1200 \mathrm{~m}$. Maan motton ore mine located in the south eastern end of the segment. Dapo ore mine located north of the western end of paragraph. Bay River ore block in between. A small amount of titanium and vanadium associated polymetallic deposits

Due to the regional tectonic and metamorphic influence, Mainland mine layer, spread with the regional tectonic and magmatic mineralization consistent. Ore significantly affected by magmatic rocks. And exist basic - ultrabasic rocks igneous complex in vivo. Significantly affected by magmatic phase controlled.

The main mining area exposed Proterozoic strata Ailaoshan group Urdu pit crew. Fung Group in Phoenix port group and some Cenozoic Quaternary stratigraphy. Now the new to the old described as follows:

Quaternary (Q): Located in the north eastern side of the mountain mining canyons, valleys area.By gray and black, brown and yellow humus, clay and sand, gravel and other components. 0 to $10 \mathrm{~m}$ thick.

Ailaoshan group Urdu pit crew (Ptw): Upper biotite augen quality mixed rock, dolomite feldspar, sillimanite migmatized quartz biotite schist Central to biotite hornblende plagioclase gneiss, hornblende banded migmatite, hornblende streaks like mixing rock-based, Clip gneiss and a small amount of biotite schist, biotite pyroxenite through. Top of marble. The lower part is migmatized gneiss and biotite hornblende plagioclase gneiss interbedded, clip a small amount of plagioclase granulite, plagioclase amphibolite, biotite schist.

Top is marble. No top, thickness unclear

, Ailaoshan group phoenix Port Group (Ptf): NW located in the south east to the north eastern side of the mine. Marble top for upper biotite hornblende plagioclase gneiss, hornblende plagioclase gneiss; Gneiss, local folder plagioclase amphibolite, biotite hornblende plagioclase leptite. The lower order (sillimanite) biotite gneiss, angle flash plagioclase gneiss, amphibolite rocks. Not bottomed out, thickness unclear

\section{A. Structure}

mine is located in north-east wing where Pengchunling duplex anticline. Anticline core of an Aaron Formation and granitic gneiss . Nancy wing and incomplete due to misappropriation of granite, rock tendencies Nancy, dip $15^{\circ} \sim 60^{\circ}$; followed by North East Wing Phoenix port group formation, group of formations Urdu pit, tend to the north east, dip $45^{\circ} \sim 80^{\circ}$. Also in the wings of the anticline has a more developed secondary folds, such as the doctor Walled anticline. 


\section{B.The engineering geological conditions}

Mine belongs to the southern edge of the YunnanGuizhou Plateau, extending southeast part of Ailao Mountains. Like altitude of about $800 \mathrm{~m}-1350 \mathrm{~m}$ and the relative height $550 \mathrm{~m}$, terrain cutting strongly orebodies on the south bank of the Gulf, the exposed elevation of about $1050 \mathrm{~m}$, from the Bay River water level in about $45 \mathrm{~m}-12 \mathrm{~m}$. As long as the ore zone lithology feldspar amphibole schist, amphibole schist, divisions range, medium-hard rock for VII level, a good solid performance for medium hard rock group, good compression performance, shear performance slightly times. Mining faults undeveloped. The combination of adjacent mines in northern Kunming Iron and Steel Company mined iron ore Dapo actual situation analysis, two engineering geological conditions similar to mine, so engineering geological conditions of the area belongs to a simple type.

However, due to weathering, the surface portion of the rock stability is poor, but with the increase of mining depth stability may have some improvement occurs in the rock above the ore body is basically similar. It is noteworthy that produced in feldspar amphibole schist and amphibole schist ore body, the belt with stone floor and wall rock or ore body contact points between the significantly strong green clay alteration phenomenon, underground easy to produce roof caving shelling hidden dangers when mining. Only the surface due to the current project, the stability of the mine rock for further observation in production, production technology in order to develop the right measures.

Lower ore and surrounding rock of free $\mathrm{SiO} 2$ content, when there is little risk to human exploitation.

\section{C. hydrogeological conditions}

This belonged to the southern edge of the YunnanGuizhou Plateau, the mountains of southeastern extension Ailaoshan

General altitude of about $800 \mathrm{~m}-1350 \mathrm{~m}$ and the relative height $550 \mathrm{~m}$, terrain cutting strong. Ore production in the Gulf south bank, Mountain Dew elevation of about 1050m, from the Bay River river 45-120m, surface water and groundwater are excreted to the east side of the Bay River. Ore mining elevation 975m-1075m, alpine Bay River riverbed $45 \mathrm{~m}-120 \mathrm{~m}$, visible above the ore body in the local water table. Lithology of ore-feldspar amphibole schist, weak aqueous rock group. Wind oxide thin topsoil cover, typically only 10 meters. Mine was no big faults, to the deep ore-bearing rock fissures and fissure water development, good natural drainage conditions of the mine. Therefore, the case of simple types hydrogeological conditions.

\section{DUMP DESIGN}

\section{A. Dump positional parameters}

1) Located in the northwest of the open pit mine

2) covers an area of $209473 \mathrm{~m} 2$

3) waste rock storage capacity of 4.7 million $\mathrm{m} 3$

4) The average haul waste rock $2 \mathrm{~km}$

\section{B. Dump design parameters}

Mine is a continuation of the mine, mine design capacity of waste rock stripped 3,236,100 m3 (solid square), consider a combination of loose factor of 1.3 , the open-air waste rock realm efflux capacity of 4,206,900 m3 (loose measure). Former mine dump open pit located in the northwest side of the valley, waste discharge area of 18896 $\mathrm{m} 2$ ranked annulment high $30 \mathrm{~m}$. Waste is currently ranked as a natural range of the western canyons, this design is recommended expansion of the original dump, expand to the west of the original dump, based on the transformation, the transformation of the rear dump a natural terrain depressions catchment area than large, design dump located around honggou cut below the dam has dregs. Dump from the open pit $750 \mathrm{~m}$, dump area $209473 \mathrm{~m} 2$, piled high $44 \mathrm{~m}$, storage capacity of approximately 4.7 million $\mathrm{m} 3$; Dump meet mine waste rock stripping outdoor realm of emissions, but in the latter part of the production if the conditions within the row when considering possible within the row.

Dregs dam dam reinforcement cage for a length of $14 \mathrm{~m}$, a height of $20 \mathrm{~m}$, outer slope ratio of $1: 1$, the slope ratio of $1: 1.5$.

Key to the formation of ground level to make the casing is made to make reasonable arrangements for production planning management, attention to arrangements in the lower row of the waste rock dump in the development of divestment plan, then ranked $0.5 \mathrm{~m} \sim$ $1 \mathrm{~m}$ topsoil or soil above the seed value stepped surface, pay attention to the well preserved mining planting soil stripping, select the appropriate place to store for future overburden reclamation use. [1 ]

Dump this project and stockpiling database design parameters, based on the type of waste rock, soil type main channel longitudinal slope, the specific design parameters are shown in Table I

TABLE I . DUMP DESIGN PARAMETER TABLE

\begin{tabular}{|l|l|l|l|l|}
\hline No. & $\begin{array}{l}\text { Storage } \\
\text { capacity } \\
(1000 \\
\left.0 \mathrm{~m}^{3}\right)\end{array}$ & $\begin{array}{l}\text { Amount of } \\
\text { waste } \\
\left(10000 \mathrm{~m}^{3}\right)\end{array}$ & $\begin{array}{l}\text { Piled up } \\
\text { high } \\
\text { total } \\
(\mathrm{m})\end{array}$ & $\begin{array}{l}\text { Period } \\
\text { of high } \\
(\mathrm{m})\end{array}$ \\
\hline dump & 470 & $323-61$ & 44 & $16-24$ \\
\hline No. & $\begin{array}{l}\text { Section } \\
\text { number }\end{array}$ & $\begin{array}{l}\text { Segmented } \\
\text { platform width } \\
(\mathrm{m})\end{array}$ & $\begin{array}{l}\text { Angle } \\
\left({ }^{\circ}\right)\end{array}$ & \\
\hline $\begin{array}{l}\text { dump } \\
\text { Remark: a table storage capacity for effective volume; } \\
\text { 2. The width of the table as a platform for staging } \\
\text { platform width steady accumulation after the final }\end{array}$ \\
formation.
\end{tabular}

In open pit as the center, according to the surrounding terrain, topography, geology, terrain and conditions of safety and capacity, in order to shorten the transportation 
distance and save on shipping as a prerequisite, as close as possible row, stockpiling. Waste rock site, determined by comparing near to far post. [2]

The waste rock terrain is high on three sides face much lower Qing ditch type topography, land requisition status quo waste rock sites, mostly pine mountain, the lower dam a small amount of dry land, no villages and industrial facilities within the range of around $1000 \mathrm{~m}$, the waste rock venue currently no engineering geology, hydrogeology data (to be performed after the engineering geology and hydrogeology exploration[3], and ultimately determine whether the use of the waste rock, and special design), waste rock venues $458 \mathrm{~m} 500 \mathrm{~m}$ lower than the minimum potential open pit mining lowest elevation $42 \mathrm{~m}$.

The waste rock venue trench about $250 \mathrm{~m}$, about $15 \mathrm{~m}$ deep, ditch the lowest elevation of $458 \mathrm{~m}$, ditch the highest elevation $473 \mathrm{~m}$, ditch longitudinal average slope of $6 \%$, waste rock ditch gentler slopes, large storage capacity, representing the relationship between neighbors simple, fast adaptation projects, the short distance from the stope, saving transportation costs.

The amount of waste rock stripping outdoor 3,236,100 $\mathrm{m} 3$, the north side of the ditch Qing stope volume is large, fully meet the requirements of mining waste pile, waste rock geological report provides a natural angle of repose of $38^{\circ}$, waste rock slope parameters are as follows:

Step height : $16 \mathrm{~m}-24 \mathrm{~m}$ $\begin{array}{llll}\text { Slope angle of } & \text { steps: } \\ \text { Platform } & & \end{array}$ Highest level waste discharge elevation: 490m

Yard waste rock design using high-level waste discharge, broken stairs face angle is 37 。 Eventually stabilize waste rock dump of waste and waste discharge Slope Angle level parameters to be waste rock Reservoir engineering geological exploration. Then finalized when hydrogeological data exploration results after submitting construction design.

\section{DUMP SECURITY MEASURES}

\section{A. Dump Security Management}

Dump based scheduling workers, waste discharge and dispatch vehicles dump Slope Security Watch, and the use of bulldozers assisted waster dump communications facilities or unloading areas should contact signal, if the job should be illuminated at night.

Predetermined order, waste discharge, must maintain an adequate safety distance between the devices.

Former dump site located shunting, before entering the dump unloading channels should stop the car unit. Unloading Road slope requirements should not be so selfslip tub[4].

Pollution and Treatment 3.2 Dump

Dump pollution produced by dust, gas and acidic water into three categories, low harmful elements in the mine ore and rock mining, there is no gas, acid water pollution, dust pollution problems only.

Dust pollution comes mainly from the abandoned waste rock transportation and unloading process, depending on the degree of pollution brittleness, hardness and external factors rocks (such as the season, wind direction, wind speed, air temperature and precipitation, etc.). The larger rock brittleness, hardness smaller, the greater the tendency to form dust. Flying dust suspended in the atmosphere, so that reduces the transparency of the atmosphere, are inhaled can cause pneumoconiosis

Dust pollution control method is to spray sprinkler dump in order to achieve the purpose of dust (in order to achieve good results, you can try using the spray calcium chloride, sodium chloride or other solution for dust suppression),

Mine stripping low levels of harmful elements in rocks, so dripping liquid rock has little impact on groundwater.

\section{B. Units Dump Reclamation}

Dump occupy a certain amount of land resources, resulting in varying degrees of damage to environmental pollution and ecological landscape. Dump reclamation work is defined remediation waste rock yard, yard waste rock controlling influence on the surrounding environment and the recovery of land. Body approach is overlaid on the dump site is not suitable for the cultivation of the soil, to create favorable conditions for farming to meet the growing needs of the plant.

Prior to mining, according to the specific geological conditions should first mining development prospects and local conditions, to develop a mine land reclamation plan and incorporated into the planning and scheduling rock mining plans, possible use as mining transportation equipment, dump complex soil slope fields and repair work and mining and rock sequence coordinated row.

\section{DUMP STABILITY ANALYSIS CLASSIFICATION DUMP}

Dump terrain slope ratio <1: 2.5 , for gentle type Dump; Dump terrain slope ratio of $\geq 1: 2.5$ When, for steep-type dump. The Dump Extension slope slope ratio> 1: 2.5, is a steep-type dump [5].

\section{A. Dump stability calculation}

Due to dump without making engineering geology and hydrogeology survey observed that this design draws Dump Dump related technical parameters were values. Dump stability computations premise is original geological terrain slope below the slip plane does not exist, design thought should also be considered in the proof of groundwater erosion, but because of the extent of the impact is difficult to make a judgment according to the available information, Calculated, assuming a potential slip plane "ABCF" stability factor FS2 = 1.31> [FS] $=1.15$ $\sim 1.30$, indicating that the assumptions underlying the slip plane "ABCF" does not exist, is stable[6]. 
TABLE II . DUMP ASSUME POTENTIAL SLIP SURFACE ABCF STABILITY ANALYSIS AND CALCULATION OF DATA TABLES

\begin{tabular}{|c|c|c|c|c|}
\hline \multirow[t]{2}{*}{ No. } & \multicolumn{4}{|c|}{ Anti-slip force $(\mathrm{kN} / \mathrm{M})$} \\
\hline & $\mathrm{R}_{\mathrm{i}}$ & \multicolumn{2}{|l|}{$\Psi_{\mathrm{i}}$} & $\Pi \Psi_{\mathrm{j}}$ \\
\hline 1 & 8192.71 & 1.001 & & 1.001 \\
\hline 2 & 16301.39 & 1.064 & & 1.065 \\
\hline 3 & 20781.37 & 0.966 & & 1.028 \\
\hline 4 & 20269.10 & 0.970 & & 0.937 \\
\hline \multicolumn{5}{|c|}{ Stability factor } \\
\hline \multirow[t]{2}{*}{ No. } & $\begin{array}{l}\text { Under the } \\
\text { sliding } \\
\text { force } \\
(\mathrm{kN} / \mathrm{M})\end{array}$ & \multicolumn{2}{|c|}{$\begin{array}{l}\text { Under the } \\
\text { sliding } \\
\text { force } \\
(\mathrm{kN} / \mathrm{M})\end{array}$} & $\begin{array}{l}\text { Under the } \\
\text { sliding force } \\
(\mathrm{kN} / \mathrm{M})\end{array}$ \\
\hline & $\mathrm{T}_{\mathrm{i}}$ & \multicolumn{2}{|r|}{$\Pi \Psi \mathrm{j}$} & $\Sigma\left(\mathrm{T}_{\mathrm{i}} \Pi \Psi_{\mathrm{j}}\right)+\mathrm{T}_{\mathrm{n}}$ \\
\hline 1 & 5192.71 & \multicolumn{2}{|r|}{1.001} & \\
\hline 2 & 9301.39 & \multicolumn{2}{|r|}{1.065} & \\
\hline 3 & 15781.37 & \multicolumn{2}{|r|}{1.028} & \\
\hline 4 & 1344.30 & \multicolumn{2}{|r|}{0.983} & \\
\hline \multicolumn{5}{|c|}{$\mathrm{F}_{\mathrm{S}}=\Sigma\left(\mathrm{R}_{\mathrm{i}} \Pi \Psi_{\mathrm{j}}\right)+\mathrm{R}_{\mathrm{n}} / \quad \Sigma\left(\mathrm{T}_{\mathrm{i}} \Pi \Psi_{\mathrm{j}}\right)+\mathrm{T}_{\mathrm{n}}=1.31$} \\
\hline
\end{tabular}

Note: 1, (stability factor) "FS" (based on the original terrain surface as a potential slip surface), to design built for load dump conditions calculated FS

2, (stability factor) "FS0" this should be based on the original substrate surface topography of the following soft soil or regolith as a potential sliding surface to a specified load condition computing, but unconditionally for engineering geological investigation, it can not be sure whether there is such a slippery surface, there is no basis for calculation.

\section{ACKNOWLEDGEMENTS}

This study was jointly supported by Natural Science Foundation of China (Grant No. 41101343), Kunming University of Science and Technology, Kunming, China, 2013, and the innovation team of ore-forming dynamics and prediction of concealed deposits, Kunming University of Science and Technology, Kunming, China, 2008.

\section{REFERENCES}

[1]Fellennius,w. Erdstatiche Berechnungenmit Reibung and Kohasion [M].Emst,Berlin(in German), 1927

[2]Bishop,A.W. 'Fhe use of the slip circle in the stability analysis of slop[J].Geotichnique. London, Vo1.5(1),1955,pp:7-17.

[3]Janbu.N. Earth Pressures and bearing capacity calculations by generalized Procedure of slices

[4]Proceedings of the fourth international conferenceon mechanics and foundation engineering, Vo1.2,1957.

[5]uang Runqiu, Wang Shi days, Zhang Zhuo yuan, Ambrose super southwest China shallow crustal dynamics of the process and environmental effects of the project $[\mathrm{M}]$ Chengdu: Sichuan University Press, 2001. [6]Jiang Tong slope and nonlinear response of loading and unloading under seismic force of stability analysis [D] Beijing: China Seismological Bureau, Institute of Geology, 2004.

[7] Rick steel. Rock slope stability analysis and deformation prediction of [D]. Chongqing University, 2006. [8] Liu Zhongyu of Engineering Geology [M]. China Electric Power Press, 2007

[9] Zhang Chao. Tailings dam stability analysis and dynamic propertie of [D]. Graduate School (Institute of Rock and Soil Mechanics) 2005 Chinese Academy of Sciences.

[10]Sunshi Guo, YANG more typical dump slope stability control technology [M] Beijing: Metallurgical Industry Press, 2011. 